\title{
Group Decision Support System (GDSS) Dengan Metode Entropy Untuk Menentukan Prioritas Antrian Layanan Rumah Sakit Menggunakan Multiple Channel Model (M/M/s)
}

\author{
Ardy Hidayat ${ }^{1}$, Reza Firsandaya Malik $^{2}$, Siti Nurmaini ${ }^{3}$ \\ ${ }^{1,2,3}$ Magister Ilmu Komputer, Fakultas Ilmu Komputer Unsri, Palembang \\ 1ardy@hiday.at, ${ }^{2}$ rezafm@unsri.ac.id, ${ }^{3}$ siti_nurmaini@unsri.ac.id \\ Penulis Korespondensi: rezafm@unsri.ac.id
}

\begin{abstract}
Abstrak
Layanan sistem antrian di Rumah Sakit mengalami masalah bahwa antrian layanan lebih lama dari pada pelayanan kesehatanya sendiri. Atas dasar hal tersebut dibutuhkan sebuah model yang mampu memberikan layanan antri yang tepat sasaran dan memberikan rasa keadilan kepada pengantri. Dalam paper ini digunakan 10 kriteria untuk menentukan prioritas antrian yakni: Faktor Risiko Penyakit, Biaya Perawatan, Tenaga Medis, Peralatan Kesehatan, Waktu tunggu, Jarak Domisili Pasien, Usia, Jenis Kelamin, Jumlah pasien yang dilayani diunit yang dituju dan Keputusan Pimpinan. Ke-10 kriteria ini agar diperoleh hasil yang lebih objektif dikombinasikan dengan Group Decision Making Tipe 2 (GDM2) dan metode entropy untuk mengevaluasi antrian model Multiple Channel Model (M/M/s). Jumlah loket layanan sangat berpengaruh terhadap jumlah antrian dan waktu layanan. Kesimpulan yang didapat bahwa menambah jumlah loket layanan sebanyak dua kali lipat dari akan memangkas $1 / 2$ dari jumlah orang yang dilayani per-satuan waktu pada setiap jalur antrian terutama direntang waktu antara jam 8.00 wib s.d. 10.00 wib. Selain itu berdasarkan penilaian Decision Maker (DM) dalam kelompok pengambil keputusan, kriteria biaya adalah faktor paling penting atau kritis ketika memberikan prioritas layanan diikuti dengan kriteria keputusan pimpinan dan faktor risiko penyakit. Penambahan kategori-kategori penyakit yang berbahaya dalam sistem antrian dapat membuat sistem ini menjadi lebih baik.
\end{abstract}

Kata kunci—antrian, Group Decision Making, Entropy, Multiple Channel Model (M/M/s)

\begin{abstract}
The queuing system service at the hospital has a problem that the service queue is longer than the health service itself. Based on the problem, we need a model that is able to provide a queuing services that are right on the target. In this paper, 10 criteria are used to determine the priority of the queue, namely: Risk Factors for Disease, Cost of Care, Medical Personnel, Medical Equipment, Waiting Time, Distance of Patient Domicile, Age, Gender, Number of patients served in the intended unit and Chairperson's Decision. These 10 criteria in order to obtain more objective results are combined with Group Decision Making Type 2 (GDM2) and entropy methods to evaluate the queue of the Multiple Channel Model $(M / M / s)$. The number of service counters is very influential on the number of queues and service times. The conclusion is that by doubling the number of service counters will cut $1 / 2$ of the number of people served per time unit on each queue, especially between 8.00 am and 10:00 a.m. Furthermore, based on the assessment of Decision Maker (DM) in the decision-making group, the cost criteria are the most important or critical factors when giving priority services, followed by the leadership decision criteria and disease risk factors. Adding dangerous disease categories in the queuing system can make this system better.
\end{abstract}

Keywords — queue, Group Decision Making, Entropy, Multiple Channel Model (M/M/s) 


\section{PENDAHULUAN}

Mengantri merupakan suatu kegiatan yang sering dilakukan atau ditemui sehari-hari. Menunggu loket kereta api, tiket bioskop, antrian jalan tol, pada bank, rumah sakit, maupun yang terdekat seperti mengantri di kasir minimarket. Gross dan Haris [1] mengatakan bahwa sistem antrian adalah kedatangan pelanggan untuk mendapatkan pelayanan, menunggu untuk dilayani jika fasilitas pelayanan (server) masih sibuk, mendapatkan pelayanan dan kemudian meninggalkan sistem setelah dilayani. Kegiatan mengantri bisa menjadi kegiatan yang tidak menyenangkan bagi sebagian orang karena kegiatan mengantri ternyata menghabiskan waktu dan membosankan, apalagi jika layanan yang membutuhkan waktu lama seperti di rumah sakit. Selain membosankan selama mengantri ada banyak sekali kegiatan lain yang seharusnya dilakukan yang tidak bisa dikerjakan. Beberapa penyebab kegiatan mengantri menjadi kegiatan yang tidak menyenangkan antara lain pilihan disiplin layanan (First Come First Serve (FCFS/FIFO), Last Come First Serve (LCFS/LIFO), Service in Random Order (SIRO), Priority Service (PS)) yang dipilih oleh penyedia jasa layanan yang memiliki konsekuensi pada setiap displin layanan yang dipilih [2]. Penyebab lain munculnya antrian karena kebutuhan layanan yang melebihi kapasitas pelayanan atau fasilitas layanan, sehingga pemakai fasilitas yang tiba tidak bisa langsung mendapat layanan disebabkan kesibukan fasilitas. Kebanyakan tambahan fasilitas dapat diberikan untuk mengurangi antrian dan bahkan untuk mencegah timbulnya antrian. Tetapi dengan memberikan pelayanan tambahan, maka akan menimbulkan biaya sehingga bisa mengurangi keuntungan. Sebaliknya bila tidak ditambahkan bisa jadi akan menyebabkan kehilangan pelanggan. Pada umumnya untuk mengurangi waktu menunggu dibutuhkan analisis mendalam, oleh sebab itu diperlukan model dan teknik untuk menganalisis hal ini.

Layanan sistem antrian di pelayanan kesehatan seperti Rumah Sakit dan Puskesmas juga mengalami hal yang sama, bahkan terkadang waktu menunggu dalam antrian layanan lebih lama dari pada pelayanan kesehatannya sendiri. Masyarakat harus mengantri lama untuk mendapat pelayanan kesehatan dengan waktu tunggu yang tak sebentar. Padahal berdasarkan standar pelayanan minimal yang terdapat dalam Keputusan Menteri Kesehatan Nomor 129/Menkes/SK/II/2008 diatur bahwa waktu tunggu untuk pasien rawat jalan adalah sama dengan 60 menit atau kurang dari 60 menit. Namun pada kenyataannya tak sedikit pasien yang bisa menunggu lebih dari waktu tunggu minimal seperti yang sudah ditetapkan pemerintah. Hal ini menyebabkan banyak pasien yang masih merasa kurang puas dengan pelayanan kesehatan yang ada saat ini. Waktu menunggu di pelayanan kesehatan dari waktu ke waktu justru semakin lama dan tidak ada perubahan. Pasien mau menunggu lama bukan karena keinginannya sendiri namun lebih karena terpaksa, hanya demi mendapat pelayanan kesehatan yang diharapkan.

Penelitian yang dilakukan oleh Imran Aslan [3] pada beberapa rumah sakit besar di Turki dengan menggunakan metode antrian Tandem Queues dan M/M/s Queue, yang berkonsentrasi pada waktu tunggu dan waktu layanan menunjukan bahwa kinerja dokter tidak juga menjadi lebih baik walaupun unit layanan atau klinik ditambah. Fakta mengejutkan bahwa rumah sakit tidak terlalu memperdulikan stress pasien saat berada lama diantrian. Rumah sakit hanya mengatur waktu antri dan layanan berdasarkan katagori janji pasien yang dijadwalkan, pasien mendesak, pasien prioritas dan pasien baru itu. Artinya ada masalah besar disisi komitmen yang harus diperbaiki. Begitu juga penelitian yang dilakukan oleh Widya dan Yohannes [4] untuk mengatasi antrian di puskemas menggunakan metode Metode DMAIC (Define, Measure, Analyze, Improve, Control) Six Sigma yang di kombinasikan dengan $M / M / s$ Queue menunjukkan bahwa dengan skenario menambahkan operator dapat menurunkan waktu tunggu sebesar 1,05 jam atau $38,9 \%$.

Ardy, et.al, (Group Decision Support System (GDSS) Dengan Metode Entropy untuk Menentukan Prioritas Antrian Layanan Rumah Sakit Menggunakan Multiple Channel Model (M/M/s)) 
Penelitian yang dilakukan oleh Beate Jahn, dkk [5] menggunakan cara simulasi yang diberi nama Discrete Event Simulation (DES) dimana hasil simulasi ini kemudian dibandingkan dengan model Markov state-transition. Menariknya pada penelitian ini juga diperkenalkan kriteria-kriteria yang dipakai untuk menentukan prioritas antrian pasien yang dilayani yakni faktor resiko dari penyakit yang diidap pasien, biaya paling mahal yang harus dikeluarkan, serta sumber daya yang dimiliki oleh rumah sakit. penelitian ini juga tidak menentukan bagaimana urutan pasien yang ada dalam antrian, kriteria-kriteria yang telah dipaparkan diatas yang menjadi patokan siapa yang harus dilayani terlebih dahulu. Penelitian yang dilakukan oleh Beate Jahn, dkk [5] ini menjadi basis dasar dari model yang dikembangkan dalam penelitian ini.

Basis kriteria-kriteria juga digunakan untuk memperbaiki layanan dan waktu antrian pasien di rumah sakit (Disha Chandra, 2017). Menggunakan model riset operasional penelitian ini menggunakan kriteria-kriteria yang terdapat dalam catatan kesehatan pasien yang tersimpan secara elektronik dan menggunakan alat bantu practice management tools. Berbagai model riset operasional telah antara lain: Patient Flow, Admission System, Retrieval of Patient Information, Examination process dan Emergency cases. Hasil penelitian ini menunjukan bahwa Appointment systems, progressive Patient flow, Patient records, Examination procedures adalah faktor-faktor yang berkontribusi paling besar terhadap waktu tunggu dan kecepatan layanan. Koordinasi antar unit juga menjadi kendala dalam kecepatan layanan. Penelitian Disha Chandra [6] juga menjadi salah satu basis pembuatan model yang dilakukan dalam penelitian ini spesifik dari cara koordinasi dan kriteria saat memprioritaskan pasien dalam antrian.

Bagaimana posisi penelitian ini jika dibandingkan dengan penelitian-penelitian sebelumnya yang telah diuraikan sebelumnya?

Penelitian ini akan membangun sebuah model antrian yang mampu mempersingkat waktu tunggu dan waktu layanan (tanpa mengurangi mutu layanan) serta menghilangkan stress pada pengantri dengan menggunakan model Multi Channel Model (Multi Chanel Multi Phase) [1] yang dikembangkan. Agar model yang dihasilkan menjadi lebih baik terutama untuk memberikan prioritas antrian maka penggunaan kriteria tertentu seperti dalam penelitian Beate Jahn, dkk [5] dan Disha Chandra [6] digunakan dalam penelitian ini dengan kriteria yang digunakan berbeda dengan kedua penelitian sebelumnya. Adapun kriteria yang digunakan dalam penelitian untuk membangun model antrian adalah Faktor Risiko Penyakit (F), Biaya Perawatan (B), Tenaga Medis (T), Peralatan Kesehatan (P), Waktu tunggu (W), Jarak Domisili Pasien dengan Rumah Sakit (JD), Usia (U), Jenis Kelamin (JK), Jumlah pasien yang dilayani diunit yang dituju (J) dan Keputusan Pimpinan (KP) [7],[8].

Untuk menyelesaiakan masalah koordinasi serta memutuskan siapa yang berhak mendpat prioritas dalam antrian seperti yang disampaikan oleh Disha Chandra [6], maka model yang dibangun ini dilengkapi dengan sebuahSistem Pendukung Keputusan Kelompok (GDSS= Group Decision Support System) tipe 2 yang dikombinasikan dengan metode Entropy[1],[2],[6],[9],[10],[11],[12]. Pilihan penggunaan GDSS adalah agar keputusan yang diambil untuk menentukan siapa yang mendapatkan prioritas antrian dan dilayani menggunakan fasilitas kesehatan di rumah sakit lebih objektif dan tidak bias. Untuk mendukung keobjektifan pengembalian keputusan dalam GDSS setiap anggota kelompok memiliki derajat yang sama, tidak ada yang lebih superior dibanding dengan yang lain.

Dalam kontribusi bagai ilmu pengetahuan, model yang dikembangkan dalam penelitian ini memberikan terutama pada area pengetahuan tentang sistem antrian dan pengambilan keputusan kelompok. Dalam bahasa sederhana bahwa model yang dihasilkan ini adalah sebuah model antrian yang dikembangkan yang mempu mempersingkat waktu antrian, mempercepat proses layanan serta memberikan skala prioritas antrian yang lebih objektif menggunakan model Multi Channel Model (Multi Chanel Multi Phase) yang dilengkapi dengan GDSS tipe 2 serta metode entropi.

Ardy, et.al, (Group Decision Support System (GDSS) Dengan Metode Entropy untuk Menentukan Prioritas Antrian Layanan Rumah Sakit Menggunakan Multiple Channel Model (M/M/s)) 


\section{METODE PENELITIAN}

\subsection{Metode Pengembangan}

Pada naskah ini metode yang digunakan adalah pengembangan sistem waterfall yang dimodifikasi pada perancangan yang secara spesifik pada bagian pemodelan model antrian Multi Channel Model (Multi Chanel Multi Phase) yang dikombinasikan dengan sebuah Group Decision Support System tipe 2 menggunakan metode Entropy. Tahapan lain seperti spesifikasi kebutuhan pengguna, analisis, perancangan, implementasi, pengujian, penerapan program, dan pemeliharaan tetap dilakukan.

\subsection{Landasan Teori}

\subsubsection{Multiple Channel Model (M/M/s)}

Sistem Multi Channel-Multi Phase ini menunjukkan bahwa setiap sistem mempunyai beberapa fasilitas pelayanan pada setiap tahap sehingga terdapat lebih dari satu pelanggan yang dapat dilayani pada waktu bersamaan [4].

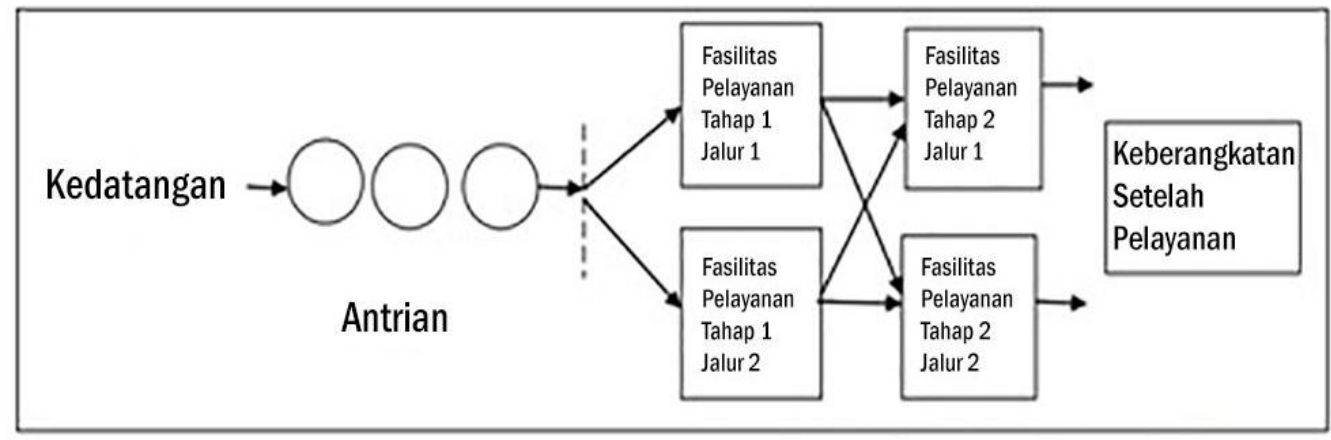

Gambar 1. Model Sistem Multi Channel-Multi

Sumber: Heizer dan Render (2005)

\subsubsection{GDSS}

GDSS adalah suatu sistem berbasis komputer yang mendukung kelompok-kelompok orang yang terlibat dalam satu tugas (tujuan) bersama. GDSS mengkombinasikan komunikasi, perhitungan, dan teknologi penunjang keputusan untuk memformulasi memberikan solusi kepada permasalahan yang tidak terstruktur di dalam beberapa orang[9],[13]. Dalam Group Decision Support System (GDSS) model pengambilan keputusan kelompok ditentukan oleh kultur, aturan, mekanisme yang ada di lingkungan organisasi pengguna GDSS tersebut atau dapat juga karena kesepakatan yang dibuat oleh pemangku kebijakan yang berhubungan dimana sistem akan dibangun[14],[15],[16].

Pengelompokan model pengambilan keputusan terbagi dalam lima (5) kelompok sebagai berikut[10],[17],[18]:1. Group decision Making 1 (GDM 1): Mendapatkan tiap preferensi dan utilitas individual, menggabungkan probabilitas dan utilitas dari setiap individual menjadi probilitas dan utilitas kelompok, menyusun peringkat utilitas dan memilih solusi terbaik; 2. Group decision Making 2 (GDM 2): bekerja dengan tiap individu dan memandu mereka untuk menghasilkan analisis keputusan yang bersifat personal. Setiap individu dalam group memilih (vote) untuk kemudian menghasilkan pilihan group. Nilai preferensi atau utilitas berupa numerik dapat digunakan untuk memperkuat preferensi kemudian dikombinasikan dengan voting; 3. Group decision Making 3 (GDM 3): memiliki seorang pengambil keputusan dengan posisi tertinggi (supra decision maker). Supra decision maker (SDM) merupakan pengambil keputusan yang mengobservasi seluruh input dan proses analisis dan pengambilan keputusan dari setiap individu, untuk kemudian menyusunnya dalam satu analisi keputusan untuk suatu group. Pilihan 
solusinya lalu diambil menurut analisis dari SDM; 4. Group decision Making 4 (GDM 4): mengumpulkan setiap anggota group dalam suatu diskusi untuk membahas masalah tertentu. Dengan diskusi, dihasilkan preferensi dan utilitas group (musyawarah) tanpa melalui tahapan mendapatkan informasi individual. Model ini harus memfasilitasi ketidakpastian dalam group, sehingga kesepakatan dalam group dapat dicapai. Jika kesepakatan tidak terjadi, maka perlu dibentuk analisis untuk mengeksplorasi area yang tidak tercapai kata sepakat dengan analisis sensitivitas dan keputusan diambil dengan konsensus tanpa adanya formal voting; 5. Group decision Making 5 (GDM 5): menggunakan teori negosiasi bahkan arbitrasi untuk memperbaiki proses interaksi antar individu dalam group dan mendiskusikan serangkaian solusi.

\subsubsection{Entropy}

Metode pembobotan entropy merupakan metode pengambilan keputusan yang memberikan sekelompok kriteria, dan menaksir preferensi suatu bobot menurut penilaian kelompok pengambil keputusan untuk menentukan tingkat prioritas masalah tertentu [10], [19], Ada beberapa langkah yang dilakukan dalam metode entropy [20],[21],[22], yakni:

a. Membuat Matrik Rating Kinerja

Matrik rating kinerja adalah nilai alternatif pada setiap kriteria dimana setiap kriteria tidak saling bergantung satu dengan yang lainnya. Matriks keputusan setiap alternatif terhadap setiap kriteria $(\mathrm{X})$, diberikan sebagai:

$$
X=\left[\begin{array}{cccc}
x_{11} & x_{12} & \ldots . & x_{1 n} \\
x_{21} & x_{21} & \ldots . & x_{2 n} \\
\ldots . & \ldots . & \ldots . & \ldots . \\
x_{m 1} & x_{m 2} & \ldots . & x_{m n}
\end{array}\right]
$$

Dimana: $\mathrm{i}=1,2, \ldots . \mathrm{n} ; \mathrm{j}=1,2, . . \mathrm{m}$;

$\mathrm{i}=$ kriteria antrian ;

$\mathrm{j}=$ jumlah pengantri yang dievaluasi;

$\mathrm{x}_{\mathrm{ij}}$ merupakan kriteria antrian ke-i $(\mathrm{i}=1,2 . ., \mathrm{n})$ terhadap pengantri $\mathrm{ke}-\mathrm{j}(\mathrm{j}=1,2, . ., \mathrm{m})$

Dalam paper terdapat sepuluh (10) kriteria yakni: Faktor Risiko Penyakit (F), Biaya Perawatan (B), Tenaga Medis (T), Peralatan Kesehatan (P), Kunjungan Pertama atau setelahnya (K), Jarak Domisili Pasien dengan Rumah Sakit (JD), Usia (U), Jenis Kelamin (JK), Jumlah pasien yang dilayani di unit yang dituju (J) dan Keputusan Pimpinan (KP) [23],[24],[25],[26],[27],[28].

\section{b. Normalisasi Tabel Data Kriteria}

Normalisasi dilakukan dengan terlebih dahulu menentukan nilai paling tinggi (maksimum) dari masing-masing proyek pada setiap kriteria. Normalisasi data nilai masingmasing proyek $(\mathrm{i}=1,2, . ., \mathrm{n})$ terhadap kriteria $(\mathrm{j}=1,2, . ., \mathrm{m})$ diberikan pada persamaan 2.

$$
d_{i}^{j}=\frac{x_{i}^{j}}{x_{i \max }^{j}}
$$

dimana:

$\mathrm{x}=$ nilai data antrian $\mathrm{K}$ ke-i terhadap kriteria antrian ke-j yang belum dinormalisasi

$\mathrm{x}_{\max }=$ nilai data antrian ke-i terhadap kriteria antrian ke-j yang belum dinormalisasi yang mempunyai nilai paling tinggi

$\mathrm{d}=$ nilai antrian ke-i terhadap kriteria antrian ke-j yang telah dinormalisasi 
Selanjutnya nilai masing-masing data yang telah dinormalisasi (persamaan 3) dijumlahkan.

$$
D_{j}=\sum_{j=1}^{n} d_{i}^{j}
$$

dimana $\mathrm{j}=1,2, \ldots, \mathrm{n}$

dengan $D_{j}$ adalah jumlah nilai data antrian yang telah dinormalisasi pada masing-masing kriteria antrian.

Perhitungan entropy untuk setiap kriteria antrian ke-j dilakukan terlebih dahulu untuk menghitung nilai $\mathrm{e}_{\max }$ dan $\mathrm{K}$. Untuk mencari nilai $\mathrm{e}_{\max }$ dan $\mathrm{K}$ diberikan pada persamaan (4) dan (5).

$$
\begin{gathered}
\mathrm{e}_{\max }=\ln \mathrm{m} ; \mathrm{m} \text { adalah jumlah proyek investasi TIK } \\
\left.K=\frac{1}{e_{\max }}\right)
\end{gathered}
$$

Perhitungan entropy untuk setiap kriteria antrian ke-j dilakukan dengan menggunakan persamaan (6).

$$
e\left(d_{j}\right)=-K \sum_{j=1}^{n} \frac{d_{i}^{j}}{D_{i}} \ln \frac{d_{i}^{j}}{D_{i}}
$$

dimana:

e $(\mathrm{dj})=$ nilai entropy pada pada masing-masing kriteria antrian ke-j $(\mathrm{j}=1,2, \ldots \mathrm{n})$.

$m^{d_{i}^{j}}=$ nilai data antrian yang telah dinormalisasi.

$\mathrm{D} i=$ jumlah nilai data antrian yang telah dinormalisasi pada masing-masing kriteria

c. Setelah mendapatkan e $\left(\mathrm{d}_{\mathrm{j}}\right)$ pada persamaan (6), selanjutnya menghitung total entropy (E) untuk masing-masing kriteria seperti ditunjukkan pada persamaan (7).

d.

$$
E=\sum_{j=1}^{n} e\left(d_{j}\right)
$$

$\mathrm{j}=$ total entropy untuk antrian ke-j dimana $\mathrm{j}=1,2, \ldots . \mathrm{n}$

e. setelah total entropy sudah dihasilkan dengan merujuk pada persamaan 7 , selanjutnya f. menghitung bobot pada setiap kriteria dengan menggunakan persamaan 8 dan 9 .

Dimana $\mathrm{j}=1,2, . . \mathrm{n}$

$$
\bar{\lambda}_{j=\frac{1}{n-E}}\left[1-e\left(d_{j}\right)\right]
$$

$$
\sum_{j=1}^{n} \bar{\lambda}_{j}= \pm 1
$$

g. Untuk menghitung bobot entropy akhir untuk setiap kriteria digunakan persamaan 10 . h.

$$
\bar{\lambda}_{\mathrm{j}}=\frac{\bar{\lambda}_{\mathrm{j}} * \mathrm{w}_{\mathrm{j}}}{\sum_{\mathrm{j}=1}^{\mathrm{n}} \bar{\lambda}_{\mathrm{j}} * \mathrm{w}_{\mathrm{j}}}
$$

Dimana $\mathrm{j}=1,2, . . \mathrm{n}$, dengan $\mathrm{n}=$ jumlah kriteria antrian

$\lambda_{\mathrm{j}}=$ bobot akhir entropy

$\mathrm{w}=$ bobot awal

Ardy, et.al, (Group Decision Support System (GDSS) Dengan Metode Entropy untuk Menentukan Prioritas Antrian Layanan Rumah Sakit Menggunakan Multiple Channel Model (M/M/s)) 


\section{HASIL DAN PEMBAHASAN}

Untuk menentukan prioritas antrian digunakan sepuluh (10) kriteria yakni: Faktor Risiko Penyakit (F), Biaya Perawatan (B), Tenaga Medis (T), Peralatan Kesehatan (P), Waktu tunggu (W), Jarak Domisili Pasien dengan Rumah Sakit (JD), Usia (U), Jenis Kelamin (JK), Jumlah pasien yang dilayani diunit yang dituju (J) dan Keputusan Pimpinan (KP) dimana setiap kriteria memiliki range nilai tertentu seperti terdapat dalam tabel 1.

Tabel 1. Kriteria Antrian dan Nilai

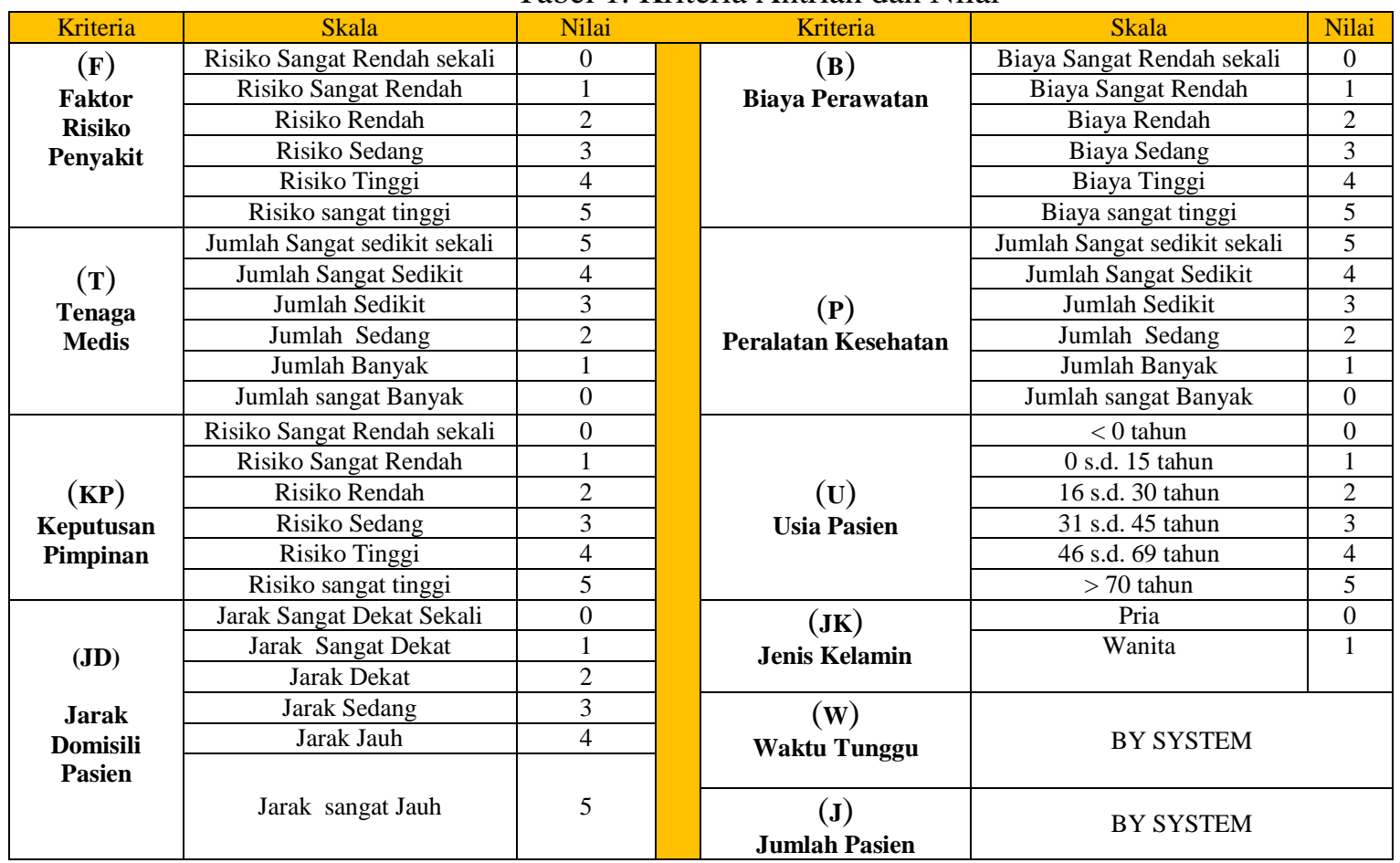

Untuk kriteria $\mathrm{W}$ dan $\mathrm{J}$ dilakukan perhitungan dengan metode antrian $\mathrm{M} / \mathrm{M} / \mathrm{S}$ dengan persamaan sebagai berikut:

$$
P_{0}=\frac{1}{\left[\sum_{N=0}^{M-1} \frac{1}{n !}\left(\frac{\lambda}{\mu}\right)\right]+\frac{1}{M !}\left(\frac{\lambda}{\mu}\right)^{M} \frac{M \mu}{M \mu-\lambda}} \text { untuk } M \mu>\lambda
$$

$\mathrm{Po}=$ Probabilitas terdapat 0 orang dalam sistem (tidak adanya pelanggan dalam sistem)

$\mathrm{M}=$ jumlah jalur yang terbuka.

$\lambda=$ jumlah kedatangan rata-rata per satuan waktu.

$\mu=$ jumlah orang dilayani per satuan waktu pada setiap jalur

$$
L_{S}=\frac{\lambda \mu(\lambda / \mu)^{M}}{(M-1) !(M \mu-\lambda)^{2}} P_{0}+\frac{\lambda}{\mu}
$$

Ls=Jumlah pelanggan rata-rata dalam sistem 


$$
W S=\frac{L_{S}}{\lambda}
$$

WS=Waktu rata-rata yang dihabiskan seorang pelanggan dalam antrian sistem

$$
L q=L_{S} \frac{\lambda}{\mu}
$$

Lq=Jumlah orang atau unit rata-rata yang menunggu dalam antrian

$$
W S=\frac{L_{q}}{\lambda}
$$

$\mathrm{Wq}=$ Waktu rata-rata yang dihabiskan oleh seorang pelanggan dalam antrian

\subsection{Pengukuran Kinerja}

Berdasarkan data pengamatan dengan rentang waktu layanan antara pukul 08.00 s.d. 15.00 Wib dimana dengan dua (2) loket layanan $(M=2)$ diperoleh hasil bahwa jumlah kedatangan rata-rata persatuan waktu adalah 19 orang $(\lambda=19)$ dan jumlah orang dilayani per satuan waktu pada setiap jalur adalah $20 \operatorname{orang}(\mu=20)$ diperoleh hasil bahwawaktu rata-rata yang dihabiskan seorang pelanggan dalam antrian sistem (WS) adalah 3,6935 menit.

Pengukuran kinerja dilanjutkan untuk mengetahui urutan prioritas antrian dari empat (4) orang yang akan dilayani dalam antrian dengan melibatkan lima (5) orang pengambil keputusan termasuk di dalamnya adalah pimpinan dari manajemen antrian ini [23],[24],[29],[30]. Sebelum dilakukan proses normalisasi, langkah pertama yang harus dilakukan adalah membuat matrik rating kinerja dimana setiap pengambil keputusan (DM) menaksir preferensi suatu bobot kriteria untuk menentukan tingkat prioritas. Matrik rating kinerja disusun berdasarkan pembobot seluruh DM terhadap kriteria dan terhadap pasien atau pengantri. Jika diterjemahkan nilai yang terdapat dalam susunan matrik kinerja misalnya untuk baris ke-1(pasien ke-1) diketahui bahwa keputusan pimpinan menyatakan bahwa pasien memiliki risiko rendah, risiko penyakit sedang, biaya perawatan sangat rendah, tenaga medis dan peralatan medis untuk menangani pasien ini jumlahnya banyak, waktu tunggu 4 menit, pasien berusia dikisaran 16 s.d. 30 tahun berjenis kelamin wanita, jumlah pasien yang dilayani saat penilaian adalah 20 orang serta jarak antara domisili dan pusat layanan kesehatan jaraknya sedang.

$$
K=\left[\begin{array}{cccccccccc}
2 & 3 & 1 & 1 & 1 & 4 & 2 & 1 & 20 & 3 \\
4 & 1 & 2 & 2 & 2 & 4 & 2 & 1 & 20 & 3 \\
3 & 4 & 1 & 2 & 2 & 4 & 2 & 1 & 20 & 3 \\
4 & 5 & 1 & 2 & 1 & 4 & 2 & 1 & 20 & 3
\end{array}\right]
$$

Normalisasi Tabel Data Kriteria. Mengacu pada persamaan (2), normalisasi dilakukan dengan terlebih dahulu menentukan nilai paling tinggi (maksimum) dari masing-masing proyek pada setiap kriteria dalam bentuk matriks.

$$
d_{i}^{j}=\left[\begin{array}{cccccccccc}
1,0 & 0,2 & 0,1 & 0,1 & 0,1 & 0,2 & 0,1 & 0,1 & 1,0 & 0,1 \\
0,2 & 0,1 & 0,1 & 0,1 & 0,1 & 0,2 & 0,1 & 0,1 & 1,0 & 0,2 \\
0,2 & 0,2 & 0,1 & 0,1 & 0,1 & 0,2 & 0,1 & 0,1 & 1,0 & 0,1 \\
0,2 & 0,3 & 0,1 & 0,1 & 0,1 & 0,2 & 0,1 & 0,1 & 1,0 & 0,2
\end{array}\right]
$$

Ardy, et.al, (Group Decision Support System (GDSS) Dengan Metode Entropy untuk Menentukan Prioritas Antrian Layanan Rumah Sakit Menggunakan Multiple Channel Model (M/M/s)) 
Selanjutnya sesuai dengan persamaan (3), nilai masing-masing data yang telah dinormalisasi dijumlahkan. Hasilnya terdapat pada tabel 2.

Tabel 2. Hasil Penjumlahan Setelah Normalisasi

\begin{tabular}{|c|c|}
\hline dmax & D \\
\hline 20 & 38 \\
\hline 20 & 40 \\
\hline 20 & 42 \\
\hline 20 & 42 \\
\hline
\end{tabular}

Perhitungan entropy untuk setiap kriteria antrian ke-j dilakukan terlebih dahulu untuk menghitung nilai $\mathrm{e}_{\max }$ dan $\mathrm{K}$. dimana diperoleh hasil $\mathrm{K}=0.721348$

Perhitungan entropy untuk setiap kriteria ke-j sesuai dengan persamaan (6) dilakukan dengan menghitung total entropy (E) untuk masing-masing kriteria (Tabel 3).

Tabel 3. Hasil Perhitungan Entropy untuk Setiap Kriteria

\begin{tabular}{ll}
\hline Entopy & Hasil \\
\hline $\mathrm{e}\left(\mathrm{d}_{1}=\mathrm{P}_{1}\right)=$ & -0.16823 \\
\hline $\mathrm{e}\left(\mathrm{d}_{2}=\mathrm{P}_{2}\right)=$ & -0.17082 \\
\hline $\mathrm{e}\left(\mathrm{d}_{3}=\mathrm{P}_{3}\right)=$ & -0.17265 \\
\hline $\mathrm{e}\left({ }_{\mathrm{d} 4}=\mathrm{P}_{4}\right)=$ & -0.1714 \\
$\mathrm{E}=-0.6831$ & \\
\hline
\end{tabular}

Perhitungan Bobot Entropy.Setelah total entropy $(E)$ sudah dihasilkan, maka dilanjutkan dengan menghitung bobot pada setiap kriteria menggunakan persamaan (7).

$$
\lambda_{1}=0.292057 ; \lambda_{2}=0.292706 ; \lambda_{3}=0.293162 ; \lambda_{4}=0.29285
$$

Perhitungan Bobot Entropy Akhir. Jika sebelumnya telah ada bobot awal kriteria atau bobot yang telah ditentukan sebelumnya maka hasil bobot entropy akhir untuk tiap kriteria dapat dihitung. Dari serangkaian proses yang dilakukan sebelumnya maka hasil akhir dari evaluasi antrian untuk empat (4) pasien adalah pasien ke-2 memperoleh prioritas layanan pertama, pasien ke-4 layanan kedua, pasien ke-3 layanan ketiga dan pasien ke-1 memperoleh layanan keempat.

$$
\lambda_{1}=0.052 ; \lambda_{2}=0.1 ; \lambda_{3}=0.071 ; \lambda_{4}=0.095
$$

\section{KESIMPULAN}

Berdasarkan pada permasalahan dan tujuan penelitian serta dihubungkan dengan hasil dan pembahasan, secara garis besar dibuat kesimpulan bahwa jumlah loket layanan sangat berpengaruh terhadap jumlah antrian dan waktu layanan. Menambah jumlah loket layanan sebanyak dua kali lipat dari akan memangkas $1 / 2$ dari jumlah orang yang dilayani per-satuan waktu pada setiap jalur antrian. Berdasarkan perhitungan jumlah antrian paling banyak yaitu direntang waktu antara jam 8.00 wib - 09.00 wib dan 09.00 wib s.d. 10.00 wib sehingga diperlukan penambahan loket layanan untuk mengatasi penumpukan antrian. 
Selain itu dapat juga disimpulkan bahwa berdasarkan penilaian DM dalam kelompok pengambil keputusan, kriteria biaya adalah faktor paling penting atau kritis ketika memberikan prioritas layanan diikuti dengan kriteria keputusan pimpinan dan faktor risiko penyakit. Sementara faktor lain belum menjadi hal yang dianggap penting ketika memberikan prioritas layanan antri.

\section{DAFTAR PUSTAKA}

[1] Gross dan Harris. 1984. The Queueing Systems. McGraw-Hill, Inc. New York.

[2] Rusdi. 2013. Analisis Penerapan Sistem Antrian Model Multiple Channel Query System $(M / M / s)$ pada Bagian Registrasi Pasien di RSUD Salewangan Maros. Skripsi Jurusan Manajemen Fakultas Ekonomi dan Bisnis Universitas Hasanuddin Makassar.

[3] Aslan, Imran. 'Applications of Queues in Hospitals In Istanbul'. 2015. Journal of Social $\begin{array}{lllllll}\text { Sciences } & \text { (COES\&RJ-JSS). } \quad I S S N & (E): & 2305-9249 & \text { ISSN } & (P): & 2305-9494\end{array}$ Publisher: Centre of Excellence for Scientific \& Research Journalism, COES \& RJ LLC Online Publication Date: 1st April 2015 Online Issue: Volume 4, Number 2.

[4] Findari, S. Widya dan Nugroho, Anton, Y,. 2019, 'Optimasi Sistem Antrian pada Layanan Kesehatan Masyarakat Menggunakan Pendekatan Simulasi', Jurnal Manajemen Industri dan Logistik Vol. 03 No. 01 Mei 2019 Page: 14-22.

[5] B. Jahn, E. Theurl, U. Siebert, and K. P. Pfeiffer,. 2010. 'Tutorial in Medical Decision Modeling Incorporating Waiting Lines and Queues Using Discrete Event Simulation', Value in Health, Vol. 13, No. 4. pp. 501-506.

[6] Chandra, Disha. 2010. 'Reducing Waiting Time of Outdoor Patients In Hospitals Using Different Types of Models: A Systematic Survey'. International Journal of Business and Management Review Vol.4, No.1, pp.79-91.

[7] Heizer, Jay dan Rander, Barry. 2004. Manajemen Operasi (Edisi Ketujuh). Salemba Empat, Jakarta.

[8] Heizer, Jay dan Rander, Barry. 2005. Operation Management Buku 2 edisi ketujuh. Salemba Empat, Jakarta,

[9] V. Tundjungsari, J. E. Istiyanto, E. Winarko, and R. Wardoyo, 2010, 'A Reputation Based Trust Model to Seek Judgment in Participatory Group Decision Making,' in Distributed Framework and Applications (DFmA), International Conference on, pp. 1-7.

[10] Ming-Chang Lee, Jui-Fang Chang, Jung-Fang Chen An. 2011. 'Entropy Decision Model for Selection of Enterprise Resource Planning System', International Journal of Computer Trends and Technology-March to April Issue.

[11] Kusumadewi, S., Hartati, S., Harjoko, A., dan Wardoyo, R., 2006, Fuzzy Multi-Attribute Decision Making (FUZZYMADM), Graha Ilmu, Yogyakarta.

Ardy, et.al, (Group Decision Support System (GDSS) Dengan Metode Entropy untuk Menentukan Prioritas Antrian Layanan Rumah Sakit Menggunakan Multiple Channel Model (M/M/s)) 
[12] W. Widhiarso, S. Hartati, R. Wardoyo. 2016, 'Group Decision Makers-Based Model for Evaluating The Feasibility of Information and Communiction Technology Project (Case Study: Local Government of Musi Rawas)', International Journal of Theoretical and Applied Information Technology, Vol. 87.

[13] Turban, Efraim, 1995, Decision Support System and Expert System, 4th ed., PrenticeHall, Inc., New Jersey, pp 472-679.

[14] Turban, Efraim and J.E Aronson, 2001, Decision Support Systems and Intelligent Systems. 6th Edition, Prentice Hall Internatinal, New Jersey.

[15] Hassan Masoumi, Farideh Ashrafe Ghanjouei, Khodabakhshe Dashgarzade and Shahram Javadi. 2013, 'Presentation of an Entropy Decision Making Pattern to Develop a Comprehensive External Evaluation Model of Sporting Federations' Performance Using Fuzzy Approach World Applied Sciences Journal 22 (12), Pp. 1718-1728.

[16] Simon, J.L., 2000, Developing Decision Making Skill forBusiness, Armonk, NY.M.E.

[17] Mauidzoh, U dan Zabidi, Y., 2007, 'Perancangan Sistem Penilaian dan Seleksi Supplier Menggunakan Multi Kriteria', Jurnal Ilmiah Teknik Industri, Volume 5, No. 3, Hal 113 122.

[18] Wang, Y., Kao, C.S., 2007, 'Applying Fuzzy Multiple Criteria Decision Making Method to Select the Distribution Center', Fourth International Conference on Fuzzy Systems and Knowledge Discovery, IEEE Computer Society. http://ieeexplore.ieee.org/xpl/freeabs_al.jps? Ar number $=4406433$, Diakses 15 Maret 2019.

[19] Ermatita, Hartati, Sri., Wardoyo, Rentantyo., Harjoko, Agus., 2012. ELECTRE-Entropy method in Group Decision Support System Modelto Gene Mutation Detection' Performance Using Fuzzy Approach', (IJARAI) International Journal of Advanced Research in Artificial Intelligence, Vol. 1, No. 1.

[20] A. De Luca, and S. Termini, 1972, "A Definition of Anon-Probabilistic Entropy in The Setting of Fuzzy Sets Theory”, Information and Control, Vol. 20, pp.201-312.

[21] Jung, F.C., Ming, C.L., dan Jui, F.C., 2011, 'An Entropy Decision Model for Selection of Enterprise Resource Planning System', International Journal of Computer Trends and Technology-March to April Issue 2011, ISSN: 2231-2803, pp1-9, National Kaohsiung University of Applied Science, Taiwan: http://www.ijcttjournal.org/volume-1/issue1/ijcttjournal-v1i1p30.pdf Diakses 18 July 2019.

[22] Wiryasaputra, Rita., 2012. Sistem Pendukung Keputusan Pengalokasian Spare Part dengan Metode Entropy dan TOPSIS. Thesis. Jurusan Ilmu Komputer dan Elektronika FMIPA UGM Yogyakarta.

[23] Aziz, S. B., Riza, T. A., \& Tulloh, R, 2015. 'Perancangan dan Implementasi Aplikasi Sistem Antrian untuk Pasien pada Dokter Umum Berbasis Android dan SMS Gateway. Elektro Telekomunikasi Terapan. 
[24] Kurniati, Rezki dan Jaroji, 2018, 'Sistem Antrian Multi Channel Rumah Sakit Berbasis Web'. Jurnal Inovtek Polbeng - Seri Informatika, Vol. 3, No. 2.

[25] Hamdani, Wardoyo, R., Mustofa, Khabib, 2018. 'Weighting Model for Group Decision Support System: A Review', Indonesian Journal of Electrical Engineering and Computer Science Vol. 11, No. 3, September 2018, pp. 962 974 ISSN: 2502-4752, DOI: 10.11591/ijeecs.v11.i3.pp962-974.

[26] Triyanti, V., dan Gadis, M.T., 2008, 'Pemilihan Supllier untuk Industri Makanan Menggunakan Promethee', Journal ofLogistics and Supply Chain Management, Volume 1, No.2, hal.83-92, http:/jurnal.pdii.lipi.go.id/admin/jurnal/1208.839.pdf, Diakses 13 Januari 2011.

[27] Xie, P., 2008, 'Development Ranking in Real Estate Strategy Management in China Based on TOPSIS Method', ISECS International Colloquium on Computing, Communication, Control, and Management, Volume 3, pp.254-258. http://www.computer.org/portal/web.

[28] Cristobal, J.R.S., Biezma, V.M., Martinez, R., and Somoza, R., 2009, 'Selection of Materials under Aggressive Environments: The Vikor Method', International Conference on Integrity, Reliability and Failure, 20-24 July 2009, pp S1204_P0266. Nautical Science Department, 2 Materials Science and Technology Department University of Cantabria Santander, Spain.

[29] Dutkova, Silvia, Achimsky, Karol and Drozdziel, Pawel., 2020, 'Simulation of A Queuing System of A Post Office In Anylogic Software', Diunduh dari https://doi.org/10.26552/com.C.2020.2.15-22, 27 Mei 2020.

[30] Hausken, K. 1997, “Game-Theoretic and Behavioral Negotiation Theory”. Group Decision and Negotiation, 6, pp.511 - 528. 